\title{
Field Performance and Laboratory Toxicity of Five Insecticides Against Black Cutworm, Agrotis ipsilon (Lepidoptera: Noctuidae)
}

\author{
Hamdy K. Abou-Taleb ${ }^{1}$, Manal A. Attia ${ }^{2}$ and S. M. Abdel Rahman ${ }^{2}$
}

\begin{abstract}
Field evaluation of four conventional insecticides and one microbial insecticide against black cutworm (BCW), Agrotis ipsilon, at two locations in cotton during 2008 and 2009 seasons were carried out in this study. Susceptibility of the two field strains compared to the laboratory strain for the five insecticides also was studied in the laboratory. At Abou-Elmatameer location, triazophos and Bacillus thuringiensis var. kurstaki revealed the highest reduction percentages of $\mathrm{BCW}$ all over the experiment period during the two seasons. Triazophos caused BCW reduction percentages 91.7, 93.2. 94.1 and 94.5\% during 2008 season, and 88.4, 90.6, 90.9 and 89.9\% during 2009 season, after 3, 6-, 9- and 12-days post-treatment, respectively. Bacillus thuringiensis kurstaki reduced $\mathrm{BCW}$ population by 68.2, 90.0, $92.7 \& 93.2 \%$ at 2008 and $69.7,87.3,90.6 \& 90.5 \%$ at 2009 after 3-, 6-, 9- and 12-days post-treatment, respectively. On the other hand, $\lambda$-cyhalothrin gave the least BCW control. At Abees location, B.t. kurstaki recorded the highest $B C W$ reduction percentages in the two seasons. During 2008, B.t. kurstaki achieved 73.7, 87.1, 90.0 and $89.4 \%$ reduction in $\mathrm{BCW}$ population after 3-, 6-, 9- and 12-days post-treatment. These reduction percentages were $71.7,90.5,89.1$ and $90.9 \%$ after $3-$-, $6-$, 9and 12-days post-treatment, respectively, at 2009. Reduction percentages of $\mathrm{BCW}$ achieved by carbosulfan, chlorpyrifos, triazophos and $\lambda$-cyhalothrin at 2008 and 2009 were comparable and significantly lower than B.t. kurstaki. Black cutworm reduction percentages achieved by carbosulfan, chlorpyrifos, triazophos and $\lambda$-cyhalothrin at Abou-El-Matameer were significantly higher than at Abees in the two seasons. On the other hand, at the two seasons, BCW reduction percentages caused by B.t. kurstaki were not significantly different at the two locations. At the laboratory, Abees strain exerts tolerance ratios higher than Abou-Elmatameer strain to the tested conventional insecticides. The two field strains had no tolerance to B.t. kurstaki compared to the laboratory strain. Therefore, B.t. kurstaki may be considered as a good alternative for controlling $\mathrm{BCW}$.
\end{abstract}

\section{INTRODUCTION}

The black cutworm (BCW), Agrotis ipsilon (Hufnagel), is found in many regions worldwide and feeds on a wide range of plants (Harrison and Lynn, 2008). In Egypt, it is an economic pest attacking field and vegetable seedlings, such as cotton, soybean, corn, potatoes and tomatoes (Abo El-Ghar et al., 1996; Abd
El-Aziz et al., 2007). Once the fourth instar is attained, larvae cause considerable damage. A larva may cut several plants in a night. The injury caused by larvae and their habits necessitates special efforts to control the pest (Zaki, 1996).

In cotton BCW causes severe damage when planting cotton after legume cover crops (Oliver and Chapin, 1981). In this case legumes serve as oviposition sites before planting, and larvae then move onto emergent cotton plants (Gaylor et al., 1984). Control of the BCW has depended exclusively on insecticides. As a result, this pest may develop resistance to those insecticides in many areas. Therefore, the continuous evaluation of the insecticides efficiency for controlling the insect in different areas became urgent. This will give the chance to replace the failed controlling agents by the effective alternatives. Moreover, the establishment of baseline susceptibility and the mechanism of resistance are necessary for effective resistance management strategies (Regupathy, 1996; Denholm et al., 1999; Mohan and Gujar, 2003).

The present study reports the effectiveness of certain insecticides in controlling the $\mathrm{BCW}$ in two areas. This study was conducted also to investigate the variation in susceptibility of two field populations of $\mathrm{BCW}$ to certain selected insecticides compared to the laboratory strain.

\section{MATERIALS AND METHODS}

Field studies: Field trials were conducted during two cotton seasons 2008 and 2009 at two different cities, Abou-Elmatameer at El-Behira Governorate and Abees at Alexandria Governorate. Cotton variety Giza 70 was cultivated at April 3 and 5 during 2008 season and April 10 and 11, during 2009 season, for the AbouElmatameer and Abees experiments, respectively. All cultural practices were carried out according to "good agricultural practice". All treatments in addition to control were assigned to plots in a randomized complete block design with four replicates (each was $100 \mathrm{~m}^{2}$ in area).

Preparation of baits: Baits were prepared as described by Salama et al., (1995). For each treatment, each insecticide at the recommended field rate (Table 1) was

${ }^{1}$ Plant Protection Research Institute, ARC, Bacous, Sabahia,

Alexandria Egypt.

${ }^{2}$ Central Pesticides Laboratory, Sabahia Station.

Received July 19, 2010, Accepted August 14, 2010 
Table 1. Evaluated insecticides and their application rates

\begin{tabular}{llc}
\hline Trade name & Common name & Rate / Fed. \\
\hline Marshal 25\%WP & carbosulfan & $1.00 \mathrm{~kg}$ \\
\hline Dursban 48\%EC & chlorpyrifos & 1.00 liter \\
\hline Hostathion 40\%EC & triazophos & 1.25 liter \\
\hline Dipel 2X 6.4\%WP & Bacillus thuringiensis kurstaki & $0.35 \mathrm{gm}$ \\
\hline Katron 5\%EC & $\lambda$-cyhalothrin & 1.00 liter \\
\hline
\end{tabular}

added to $100 \mathrm{ml}$ water. Each insecticide solution was added to bran $(2.5 \mathrm{~kg})$, and molasses $(0.4 \mathrm{~kg})$ were then added and mixed well. Water was added gradually by suitable volumes (approx. 1 liter) as the baits required. Baits were prepared just before field application and the ingredients were completely mixed to ensure homogenous distribution of the ingredientsSowing date were on 3 and 5 May in the two seasons, respectively.

Field application of baits: The baits were distributed manually on the soil surface behind each hill. Application dates were May 5 and 6, for the AbouElmatameer and Abees experiments, respectively, during 2008 season and May 10 and 11, for the AbouElmatameer and Abees experiments, respectively, during 2009 season.

Estimation of infestation by BCW larvae: The pretreatment counts of BCW larvae / 25 plants in each replicate (100 plants per each treatment) were made one day before the treatment. The numbers of BCW larvae / 25 plants in each replicate were counted 3, 6, 9 and 12 days post-treatment. Reduction percentages in the $\mathrm{BCW}$ larvae were calculated according to the formula of Henderson and Tilton (1955). The treatments were compared with each other using one way ANOVA with $\mathrm{LSD}_{0.05}$ (CoStat Statistical Software, 1990).

Laboratory bioassay: Laboratory strain of the BCW was obtained from Plant Protection Research Institute and reared on castor oil plant leaves away from any insecticidal contamination under controlled laboratory conditions at $27 \pm 2^{\circ} \mathrm{C}$ and $65 \pm 5 \%$ R.H. Larvae of field strains (Abou-El-Matameer and Abees) were collected during 2009 season from untreated areas, transferred to the laboratory and reared as described above for one generation to be used for the laboratory bioassay. Toxicity of the insecticides (Table 1) against the $2^{\text {nd }}$ instar larvae of $\mathrm{BCW}$ was evaluated. Homogenous pieces of the castor oil leaves were dipped in a series of each insecticide concentrations for $10 \mathrm{sec}$., held vertically to allow excess solution to drip off and dried at room temperature. Treated castor oil leaf pieces were transferred to a plastic cups, and 10 starved larvae were added. Each concentration was replicated five times. Mortality percentages were recorded after $24 \mathrm{hr}$ of treatment for the synthetic insecticides and after 4 days for $B$. $t$. Mortality percentages were corrected according to Abbott equation (Abbott, 1925) and subjected to probit analysis (Finney, 1971).

\section{RESULTS}

Field experiments:

Reduction percentages of $\mathrm{BCW}$ population after different time intervals of insecticides application at Abou-Elmatameer region are presented in Tables (2 and 3). All insecticides except B.t. kurstaki had high reduction percentages after 3-days of insecticides application. All over the experiment period, triazophos and B.t. kurstaki revealed the highest reduction percentages of BCW. Triazophos caused BCW reduction percentages $91.7,93.2$. 94.1 and $94.5 \%$ after 3-, 6-, 9- and 12-days post-treatment, respectively, during 2008 season. These reduction percentages were $88.4,90.6,90.9$ and $89.9 \%$ after the same days posttreatment, during 2009 season. Bacillus thuringiensis kurstaki reduced BCW population by $68.2,90.0,92.7 \&$ $93.2 \%$ at 2008 and $69.7,87.3,90.6 \& 90.5 \%$ at 2009 after 3-, 6-, 9- and 12-days post-treatment, respectively. On the other hand, $\lambda$-cyhalothrin gave the lowest reduction percentages $75.5,78.4,79.1 \& 78.3 \%$ at 2008 and 74.0, 75.6, 74.2 \& 72.7\% at 2009 after 3-, 6-, 9- and 12-days post-treatment, respectively (Tables 2 and 3 ).

Data in Tables (4 and 5) show the reduction percentages in $\mathrm{BCW}$ population due to the tested insecticides in the Abees experiments (2008 and 2009 seasons). It is clear that, the highest $\mathrm{BCW}$ reduction percentages in the two seasons were recorded by B.t. kurstaki. During 2008 season, B.t. kurstaki achieved 73.7, 87.1, 90.0 and $89.4 \%$ reduction in BCW population after 3-, 6-, 9- and 12-days post-treatment (Table 4). Reduction percentages were 71.7, 90.5, 89.1 and $90.9 \%$ after 3-, 6-, 9- and 12-days post-treatment, respectively, at 2009season (Table 5). Reduction percentages of BCW achieved by carbosulfan, chlorpyrifos, triazophos and $\lambda$-cyhalothrin at 2008 and 2009 were comparable and significantly lower than B.t. kurstaki.

Comparison between the field performances of each tested insecticide at Abou-El-Matameer and Abees experiments in the two seasons are presented in Figure (1). It is obvious that, $\mathrm{BCW}$ reduction percentages 
achieved by carbosulfan, chlorpyrifos and triazophos at Abou-Elmatameer were significantly higher than at Abees at the two seasons. On the other hand, in the two seasons, BCW reduction percentages caused by B.t. kurstaki and $\lambda$-cyhalothrin were not significantly different at the two locations.

Toxicity of tested insecticides against the $2^{\text {nd }}$ instar larvae of $\mathrm{BCW}$ in the laboratory:

Susceptibility of field strains of BCW compared to the laboratory strain for carbosulfan, chlorpyrifos, triazophos, $\lambda$-cyhalothrin and B.t. kurstaki is given in

Table 2. Black cutworm reduction percentages after different time intervals of insecticides application at Abou-Elmatameer during 2008 season

\begin{tabular}{lllll}
\hline \multirow{2}{*}{ Treatments } & \multicolumn{3}{c}{ \%Reduction } & 9-days \\
\cline { 2 - 5 } & 3-days & 6-days & $83.1 \mathrm{~b}$ & $83.7 \mathrm{~b}$ \\
\hline Carbosulfan & $84.6 \mathrm{~b}$ & $84.9 \mathrm{~b}$ & $84.3 \mathrm{~b}$ & $83.1 \mathrm{~b}$ \\
\hline Chlorpyrifos & $82.1 \mathrm{~b}$ & $83.5 \mathrm{~b}$ & $94.1 \mathrm{a}$ & $94.5 \mathrm{a}$ \\
\hline Triazophos & $91.7 \mathrm{a}$ & $93.2 \mathrm{a}$ & $79.1 \mathrm{c}$ & $78.3 \mathrm{c}$ \\
\hline$\lambda$-cyhalothrin & $75.5 \mathrm{c}$ & $78.4 \mathrm{c}$ & $92.7 \mathrm{a}$ & $93.2 \mathrm{a}$ \\
\hline B.t. kurstaki & $68.2 \mathrm{~d}$ & $90.0 \mathrm{a}$ & $\mathrm{S}$
\end{tabular}

Within the same column, numbers followed by the same letters are not significantly different according to Student-Newman Keuls (SNK) test (LSD at $\mathrm{P}<0.05)$.

Table 3. Black cutworm reduction percentages after different time intervals of insecticides application at Abou-Elmatameer during 2009 season

\begin{tabular}{lcccc}
\hline \multirow{2}{*}{ Treatments } & \multicolumn{3}{c}{ \%Reduction } \\
\cline { 2 - 5 } & 3-days & 6-days & 9-days & 12-days \\
\hline Carbosulfan & $78.5 \mathrm{~b}$ & $80.8 \mathrm{~cd}$ & $79.7 \mathrm{~cd}$ & $79.4 \mathrm{~b}$ \\
\hline Chlorpyrifos & $80.1 \mathrm{~b}$ & $82.5 \mathrm{bc}$ & $83.1 \mathrm{bc}$ & $82.0 \mathrm{~b}$ \\
\hline Triazophos & $88.4 \mathrm{a}$ & $90.6 \mathrm{a}$ & $90.9 \mathrm{a}$ & $89.9 \mathrm{a}$ \\
\hline$\lambda$-cyhalothrin & $74.0 \mathrm{c}$ & $75.6 \mathrm{~d}$ & $74.2 \mathrm{~d}$ & $72.7 \mathrm{c}$ \\
\hline B.t. kurstaki & $69.7 \mathrm{~d}$ & $87.3 \mathrm{a}$ & $90.6 \mathrm{a}$ & $90.5 \mathrm{a}$ \\
\hline
\end{tabular}

Within the same column, numbers followed by the same letters are not significantly different according to Student-Newman Keuls (SNK) test (LSD at $\mathrm{P}<0.05$ ).

Table 4. Black cutworm reduction percentages after different time intervals of insecticides application at Abees during 2008 season

\begin{tabular}{lcccc}
\hline \multirow{2}{*}{ Treatments } & \multicolumn{4}{c}{ \%Reduction } \\
\cline { 2 - 5 } & 3-days & 6-days & 9-days & 12-days \\
\hline Carbosulfan & $70.3 \mathrm{a}$ & $73.5 \mathrm{~b}$ & $76.2 \mathrm{~b}$ & $75.7 \mathrm{~b}$ \\
\hline Chlorpyrifos & $68.1 \mathrm{a}$ & $70.6 \mathrm{~b}$ & $71.4 \mathrm{~b}$ & $73.2 \mathrm{~b}$ \\
\hline Triazophos & $73.4 \mathrm{a}$ & $75.2 \mathrm{~b}$ & $75.7 \mathrm{~b}$ & $76.0 \mathrm{~b}$ \\
\hline$\lambda$-cyhalothrin & $74.0 \mathrm{a}$ & $76.2 \mathrm{~b}$ & $75.3 \mathrm{~b}$ & $76.4 \mathrm{~b}$ \\
\hline B.t. kurstaki & $73.7 \mathrm{a}$ & $87.1 \mathrm{a}$ & $90.0 \mathrm{a}$ & $89.4 \mathrm{a}$ \\
\hline
\end{tabular}

Within the same column, numbers followed by the same letters are not significantly different according to Student-Newman Keuls (SNK) test (LSD at $\mathrm{P}<0.05)$.

Table 5. Black cutworm reduction percentages after different time intervals of insecticides application at Abees during 2009 season

\begin{tabular}{lcccc}
\hline \multirow{2}{*}{ Treatments } & \multicolumn{3}{c}{ \%Reduction } \\
\cline { 2 - 5 } & 3-days & 6-days & 9-days & 12-days \\
\hline Carbosulfan & $69.4 \mathrm{a}$ & $72.1 \mathrm{~b}$ & $73.2 \mathrm{~b}$ & $71.3 \mathrm{~b}$ \\
\hline Chlorpyrifos & $73.9 \mathrm{a}$ & $74.5 \mathrm{~b}$ & $74.3 \mathrm{~b}$ & $73.7 \mathrm{~b}$ \\
\hline Triazophos & $74.9 \mathrm{a}$ & $76.1 \mathrm{~b}$ & $76.3 \mathrm{~b}$ & $77.1 \mathrm{~b}$ \\
\hline$\lambda$-cyhalothrin & $72.0 \mathrm{a}$ & $73.6 \mathrm{~b}$ & $74.7 \mathrm{~b}$ & $73.8 \mathrm{~b}$ \\
\hline B.t. kurstaki & $71.7 \mathrm{a}$ & $90.5 \mathrm{a}$ & $89.1 \mathrm{a}$ & $90.9 \mathrm{a}$ \\
\hline
\end{tabular}

Within the same column, numbers followed by the same letters are not significantly different according to Student-Newman Keuls (SNK) test (LSD at $\mathrm{P}<0.05)$. 
Table 6. Median lethal concentrations, confidence limits (CL) and slope \pm standard errors of five selected insecticides against the $2^{\text {nd }}$ instar larvae of black cutworm

\begin{tabular}{clcccc}
\hline Insecticides & Insect strain & $\mathbf{L C}_{\mathbf{5 0}}(\mathbf{p p m})$ & $\mathbf{9 5 \%} \mathbf{C L}$ & $\mathbf{S l o p e} \pm \mathbf{S E}$ & TR* $^{*}$ \\
\hline Carbosulfan & Lab. & 6.8 & $5.1-9.4$ & $1.8 \pm 0.24$ & 1.0 \\
\cline { 2 - 6 } & Abou-Elmatameer & 25.0 & $19.5-31.8$ & $1.9 \pm 0.30$ & 3.68 \\
\cline { 2 - 6 } & Abees & 48.6 & $36.3-61.4$ & $1.8 \pm 0.27$ & 7.15 \\
\hline \multirow{2}{*}{ Chlorpyrifos } & Lab. & 5.7 & $3.8-6.8$ & $2.4 \pm 0.37$ & 1.0 \\
\cline { 2 - 6 } & Abou-Elmatameer & 10.8 & $7.4-15.4$ & $1.7 \pm 0.31$ & 1.89 \\
\cline { 2 - 6 } & Abees & 49.4 & $36.1-64.3$ & $1.9 \pm 0.29$ & 8.67 \\
\hline \multirow{2}{*}{ Triazophos } & Lab. & 3.6 & $1.6-5.7$ & $2.4 \pm 0.44$ & 1.0 \\
\cline { 2 - 6 } & Abou-Elmatameer & 6.6 & $4.0-9.3$ & $2.5 \pm 0.37$ & 1.83 \\
\cline { 2 - 6 } & Abees & 22.3 & $13.9-35.8$ & $2.1 \pm 0.23$ & 6.19 \\
\hline \multirow{2}{*}{-cyhalothrin } & Lab. & 4.7 & $3.8-6.0$ & $2.1 \pm 0.33$ & 1.0 \\
\cline { 2 - 6 } & Abou-Elmatameer & 6.3 & $5.2-7.6$ & $1.9 \pm 0.24$ & 1.34 \\
\cline { 2 - 6 } & Abees & 11.1 & $8.4-15.2$ & $2.2 \pm 0.37$ & 2.36 \\
\hline \multirow{2}{*}{ B.t. kurstaki } & Lab. & 12.6 & $8.2-18.1$ & $1.6 \pm 0.18$ & 1.0 \\
\cline { 2 - 6 } & Abou-Elmatameer & 14.8 & $9.6-20.0$ & $1.7 \pm 0.12$ & 1.17 \\
\cline { 2 - 6 } & Abees & 15.8 & $10.1-24.8$ & $1.8 \pm 0.20$ & 1.25 \\
\hline
\end{tabular}

$* \mathrm{TR}=$ Tolerance ratio $\left(\mathrm{LC}_{50}\right.$ of field strain $/ \mathrm{LC}_{50}$ of laboratory strain).

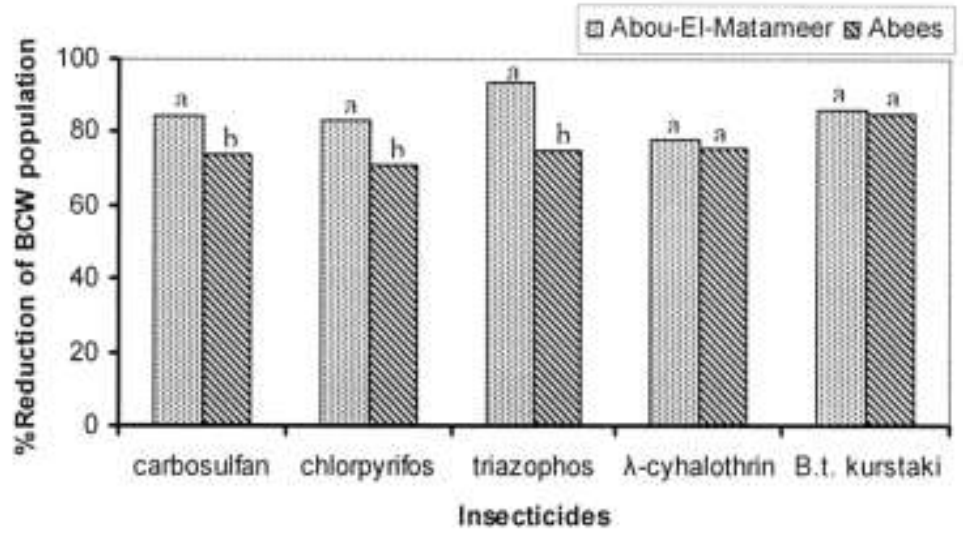

2008

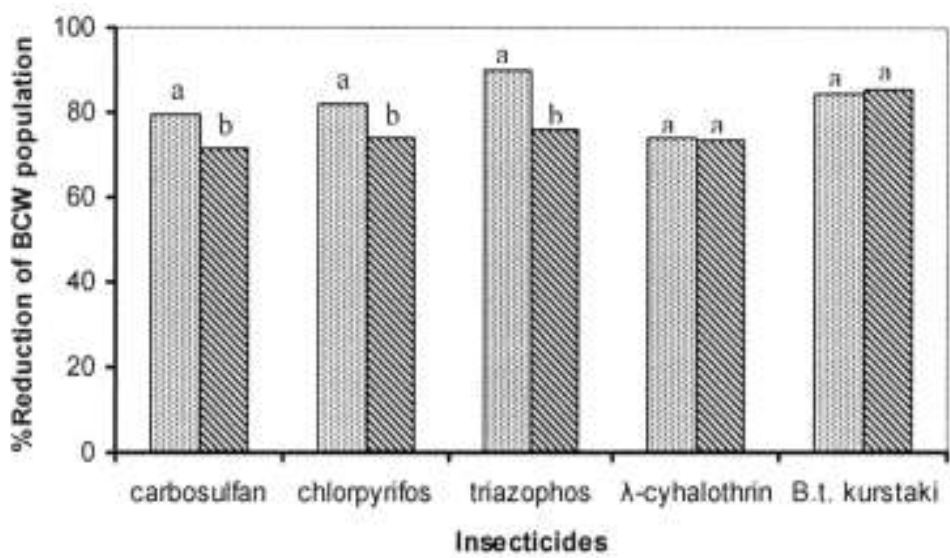

Figure 1. Comparison between reduction percentages of black cutworm achieved by the tested insecticides at Abou-El-Matameer and Abees at 2008 and 2009 seasons. Columns within a group with a letter in common are not significantly different according to StudentNewman Keuls (SNK) test (LSD at $P<0.05)$ 


\section{DISCUSSION}

The black cutworm is one of the most severe insect pests in Egypt. The growers usually use the conventional insecticides, especially organophosphorus compounds, in controlling this pest. However, the intensive use of pesticides has resulted in environmental contamination (Frank et al., 1990; Abd El-Aziz et al., 2007). In this study, field performance of four synthetic insecticides and one bioinsecticide against $\mathrm{BCW}$ was evaluated. The bioinsecticide (depending on the B.t. kurstaki) is considered as a possible substitute and as a mean of reducing the use of chemicals in the environment. Results revealed that, all over the experiment period, triazophos and B.t. kurstaki revealed the highest reduction percentages of $\mathrm{BCW}$. These results are in agreement with the results which reported by Salama $e t$ al., (1995). They found that, Dipel $2 \mathrm{X}^{\circledR}$ (B.t. kurstaki) and Hostathion ${ }^{\circledR}$ (triazophos) baits revealed a considerable BCW control in soybean fields. They concluded that, the use of biocontrol agent Dipel $2 \mathrm{X}^{\circledR}$ to control the $\mathrm{BCW}$ is of great value to soybean cultivations to avoid the residues of chemical insecticides on the seeds used to produce oil. In addition, the use of B.t. kurstaki was less harmful to the natural predators and parasites. Among the tested insecticides, $\lambda$-cyhalothrin, which gave the lowest $\mathrm{BCW}$ control. In respect of the $\lambda$-cyhalothrin, our results are at variance with those obtained by Mohamed, (2009). He reported that $\operatorname{Karate}^{\circledR}$ ( $\lambda$-cyhalothrin) was significantly effective and gave the superior results in controlling $\mathrm{BCW}$ in commercial potato production fields.

The initial BCW reduction percentages (3-days after treatment) revealed by B.t. kurstaki at Abou-Elmatameer was low compared to the tested conventional insecticides. This may refer to the mode of action of B.t (need a time) which include 1) ingestion of sporulated B.t and insecticidal crystal protein (ICP) by an insect larva; 2) solubilization of the crystalline ICP in the midgut; 3 ) activation of the ICP by proteases; 4) binding of the activated ICP to specific receptors in the midgut cell membrane; 5) insertion of the toxin in the cell membrane and formation of pores and channels in the gut cell membrane, followed by destruction of the epithelial cells (Fast, 1981; Lüthy \& Ebersold, 1981; Smedley \& Ellar, 1996).

According to the laboratory bioassay, AbouElmatameer strain showed low tolerance ratios, while Abees strain showed higher tolerance ratios to the tested conventional insecticides. The two field strains had no tolerance to B.t. kurstaki compared to the laboratory strain. These results are in accordance with the field performance of these insecticides. Our results indicated to $\mathrm{BCW}$ reduction percentages achieved by carbosulfan, chlorpyrifos and triazophos at Abou-Elmatameer were significantly higher than at Abees at the two seasons. On the other hand, at the two seasons, BCW reduction percentages achieved by B.t. kurstaki were not different at the two locations. Therefore, B.t. kurstaki may serve as a good alternative to these insecticides in controlling the BCW in cotton fields.

Finally, further studies are needed to establish why $\mathrm{BCW}$ is showing the tolerance to the carbamate insecticide (carbosulfan) and the two organophosphorus insecticides (chlorpyrifos and triazophos) at Abees location. Also, further studies are needed to show the mechanisms of this tolerance.

\section{REFERENCES}

Abbott, W. S. (1925). A method for computing the effectiveness of an insecticide. J. Econ. Entomol. 18: 265267.

Abd El-Aziz, S. E; E. A. Omer and A. S. Sabra (2007). Chemical composition of Ocimum americanum essential oil and its biological effects against Agrotis ipsilon, (Lepidoptera: Noctuidae). Res. J. Agric. Biol. Sci., 3: 740747.

Abo El-Ghar, G. E. S.; M. E. Khalil and T. M. Eid (1996). Some biochemical effects of plant extracts in the black cutworm, Agrotis ipsilon (Hufnagel) (Lepidoptera: Noctuidae). J. Appl. Entomol., 120: 477-482.

CoStat Statistical Software (1990). Microcomputer program analysis version 4.20, CoHort Software, Berkeley, CA.

Denholm, I.; J. A. Pickett and A. L. Devonshire (1999). Insecticide resistance: from mechanisms to management. CAB International and Royal Society, London, p. 123.

Fast, P. G. (1981). The crystal toxin of Bacillus thuringiensis. In: Microbial control of pests and plant diseases 19701980 (Burges H. D., ed.), New York, London, Academic Press Inc., pp. 223-248.

Finney, D. J. (1971). Probit analysis, $3^{\text {rd }}$ Ed. Cambridge Univ. Press, Cambridge. p. 380.

Frank, R.; H. E. Braun; B. D. Ripely and B.S. Clegg (1990). Contamination of rural ponds with pesticides, $1971-85$, Ontario, Canada. Bull Environ Contam Toxicol., 13: 771717.

Gaylor, M. J.; S. J. Fleischer; D. P. Muhleison and J. V. Edelso (1984). Insect populations in cotton produced under conservation tillage. J. Soil Water Conserve, 39: 6164.

Harrison, R. L. and D. E. Lynn (2008). New cell lines derived from the black cutworm, Agrotis ipsilon, that support replication of the $A$. ipsilon multiple nucleopolyhedrovirus and several group I nucleopolyhedroviruses. J. Invertebr. Pathol., 99: 28-34. 
Henderson, C. F. and E. W. Tilton (1955). Tests with acaricides against the brown wheat mite. J. Econ. Entomol., 48: 157-161.

Lüthy, P. and H. R. Ebersold (1981). The entomocidal toxins of Bacillus thuringiensis. Pharmacol. Ther., 13: 257-283.

Mohamed, E. S. I. (2009). Evaluation of the efficacy of four pyrethroid insecticides and bioinsecticide (Agerin) for the control of black cutworm Agrotis ipsilon (Hufnagel). Arab Journal of Plant Protection (Special Issue, Abstracts Book $10^{\text {th }}$ Arab Congress of Plant Protection). 27: 21.

Mohan, M. and G.T. Gujar (2003). Local variation in susceptibility of the diamond back moth, Plutella xylostella (Linnaeus) to insecticides and role of detoxification enzymes. Crop Protection, 22: 495-504.

Oliver, A. D. and J. B. Chapin. (1981). Biology and illustrated key for the identification of twenty species of economically important noctuid pests. La. State Univ. Agric. Exp. Stn. Bull., 733.
Regupathy, A. (1996). Insecticide resistance in diamondback moth (DBM), Plutella xylostella (L.): Status and prospects for its management in India. In: Proceedings of the Third International Workshop, the Management of Diamondback Moth and Other Crucifer Pests. (Sivapragasam, A., Loke, W.H., Hussan, A.K., Lim, G.S., Eds.), Kuala Lumpur, Malaysia, pp. 233-242.

Salama, H. S.; F. N. Zaki; S. Salem and M. Ragae (1995). The use of Bacillus thuringiensis to control two lepidopterous insect pests (Agrotis ypsilon and Spodoptera littoralis). Anz. Schadlingskde., Pflanzenschutz, Umweltschutz, 68: 15-17.

Smedley, D. P. and D. J. Ellar (1996). Mutagenesis of 3 surface-exposed loops of a Bacillus thuringiensis insecticidal toxin reveals residues important for toxicity, recognition and possibly membrane insertion. Microbiology, 142: 1617-1624.

Zaki, F. N. (1996). Field application of Steinernema feltiae in the form of baits against the greesy cutworm Agrotis ipsilon in an Okra field in Egypt. Anz. Schadlingskde., Pflanzenschutz, Umweltschutz. 69: 79-80. 


\title{
الملخص العربي
}

\section{Agrotis ipsilon الكفاءة الحقلية والسمية المعملية لبعض المبيدات ضد الدودة القارضة}

\section{(Lepidoptera: Noctuidae)}

\author{
حمدى قطب أبوطالب، منال أحمد عطية، صفاء مصطفى عبدالرحمن
}

عند مقارنة فاعلية المبيدات المستخدمة على الدودة القارضة في

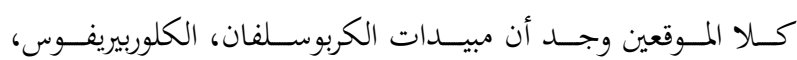

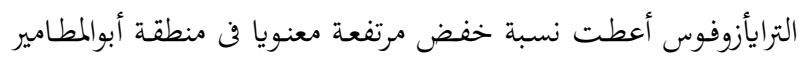

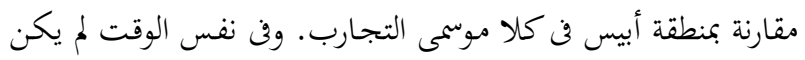
هناك فرقا معنويا بين الموقعين بالنسبة لفاعلية الباسيلس ثيورينجينزز

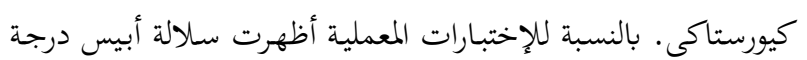

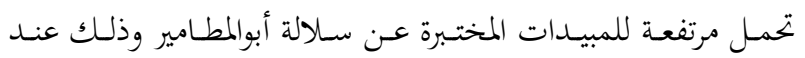

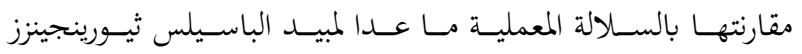

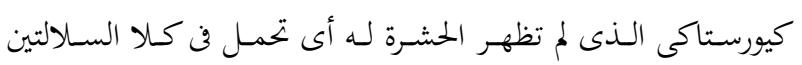

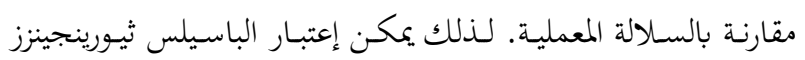
كيورستاكى وسيلة مكافحة بديلة للمبيدات التقليدية للدودة القارضة.
فن هذه الدراسة تم التقييم الحقلى لأربعة مبيدات تقليدية وأحسد

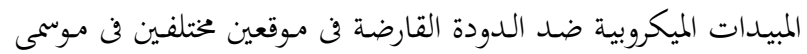
2008، 2009. أيضـا تم مقارنسة حساسـية السـالتين الحقليتسين

للخمسة مبيدات بالمقارنة بالسلالة المعملية في المعمل.

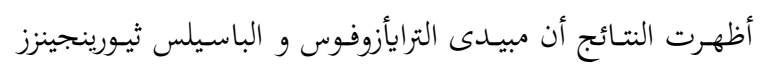

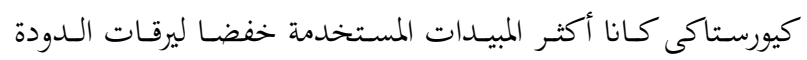

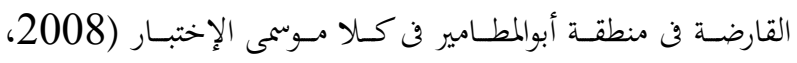

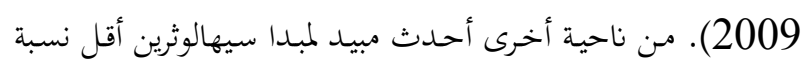

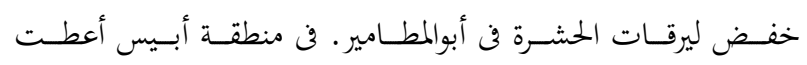
الباسيلس ثيورينجينز كيورستاكى أعلى خفض لتعداد يرقات الدودة

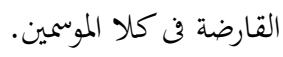

